\title{
Effect of Net Colours on Efficiency of Monofilament Gillnets for Catching Some Fish Species in the Lake Volta at Kpong
}

\section{Hlordzi $V^{1-4}$, Akongyuure DN ${ }^{6 *}$ and Kuebutornye FKA ${ }^{1,5}$}

${ }^{1}$ College of Fishery, Guangdong Ocean University, China

${ }^{2}$ Laboratory of Aquatic Animal Nutrition and Feed, College of Fisheries, Guangdong Ocean University, China

${ }^{3}$ Key Laboratory of Aquatic, Livestock and Poultry Feed Science and Technology in South China, Ministry of Agriculture, China

${ }^{4}$ Aquatic Animals Precision Nutrition and High-Efficiency Feed Engineering Research Centre of Guangdong Province, China

${ }^{5}$ Guangdong Key Laboratory of Control for Diseases of Aquatic Economic Animals, China

${ }^{6}$ Department of Fisheries and Aquatic Resources Management, University for Development Studies, Ghana

*Corresponding author: Daniel Nsoh Akongyuure, Department of Fisheries and Aquatic Resources Management, University for Development Studies, TL 1350, Tamale, Ghana, Email : nsohdan@yahoo.com

\section{Abstract}

A net is visible depending on the net colour and the tone variation with its background; it can also be affected by the time of day, and the seasonal changes in water clarity or colour. Fish can differentiate between colours, and also different coloured nets may show significant differences in catches. The main objective of the study was to identify the net colour with the most fish capture. The green net caught the highest number of fishes thus 36 fishes, which consisted of 14 species with a total weight of $3.536 \mathrm{~kg}$, an average length of $22.47 \mathrm{~cm}$. The white net caught the next highest number of fishes; thus $27 \mathrm{fishes,}$ which consisted of nine (9) species with a total weight of $3.743 \mathrm{~kg}$ and an average length of $28.69 \mathrm{~cm}$. Eight (8) species, 15 fishes were caught by the brown net which was the least number caught with a total weight of $1.617 \mathrm{~kg}$ and an average length of $24.2 \mathrm{~cm}$. Fishers should be educated so they know the colour of net used has an effect on fish catch. Studies should be carried out on the hanging ratio and thickness of the monofilament gillnets to know if it would affect fish catch. Further studies should be carried out on this study for the whole year to check if there would be changes in results. Marcusenius abadii was the species caught most during this experiment, followed by Synodontis ocellifer, Sarotherodon galilaeus, Hemichromis fasciatus, Chrysichthys auratus, Oreochromis niloticus, Clarias gariepinus, Mormyrops anguilloides, Tilapia zillii, Heterotis niloticus, Marcusenius senegalensis, Gymnarchus niloticus, Parachanna obscura, Synodontis bastiani, Chromidotilapia guntheri, Synodontis schall, and Mormyrops breviceps.

Keywords: Gillnet; Operculae; Gilling; Wedged; Entangle

\section{Introduction}

The significant growth in fish consumption has improved people's diets around the world through different and nutritious food. In 2013, fish contributed to about 17 percent of the global population's consumption of animal protein and 6.7 percent of all protein consumed. Moreover, fish provided more than 3.1 billion people with almost 20 percent of their average per capita intake of animal protein [1]. Apart from being a rich source of easily assimilated food, high quality proteins containing all essential amino acids, fish provides essential fats (e.g. long chain omega-3 fatty acids), vitamins (D, A and B) and minerals (including calcium, iodine, zinc, iron, and selenium) particularly if eaten whole [1]. Even small amounts of fish can have a significant positive nutritional impact on plant-based diets, and this is the case in many 
Low Income Food Deficient Countries (LIFDCs) and leastdeveloped countries. Fish is usually high in unsaturated fats and provides health benefits in protection against cardiovascular diseases. It also helps in the development of the brain and nervous system of foetus and infants [1].

Many gears such as gillnets, traps and hook and lines are used in capture fisheries with the most common type being the gillnet [2]. A monofilament gillnet is one which is made of single strands of a synthetic material that looks like a strand of modern fishing line [3]. Gillnets are normally a rectangular sheet of netting which is hanged in a water body like a curtain to trap or catch fish by the gills (operculae) as they try to swim through the mesh of the net [4].

The term "gilling" refers to the way fishes gill cover may act as barbs to prevent them from escaping after been trapped in the meshes of nets. Gillnets are commonly used in the coastal and inland fisheries of the world because of their flexibility, low cost, and ease of operation [5]. Gillnet is one of the oldest types of fishing gear and is widely used to harvest different marine and freshwater species [6]. Gillnets are known passive gears, consisting of a large wall of netting which can be set at or below the surface on the sea bed, or any depth in between [7]. Its construction can be single, double or triple (trammel net) netting. Depending on the operation, a gillnet can be drifting, fixed or encircling. Fish caught in gillnets are usually gilled, but can be wedged, snagged or entangled [8-10].

Nets are made up of a single or multiple layers of monofilament mesh in which the fish is trapped in its gill, wedged when it is caught by the largest part of the body or entangled when the fish is held in the net by teeth, maxillaries, fins or other projections, without necessarily penetrating the mesh [11].

Visibility of the nets depends on net colour, the tone contrast with the background and species of fish, which might be affected by the time of day, and the seasonal changes in water clarity or colour [12]. Fish can differentiate between colours, hence different coloured nets may show significant differences in catches [13]. Gillnets are made with fine twines that are chosen to be relatively invisible to the fish, particularly at low light intensities. When a net is invisible, the target fish are unaware of its presence and hence swim into it, and may become trapped by the meshes [14].

Many fishermen use different methods and techniques both modern and traditional to increase their catch which comes with a cost either financially or sometimes leads to environmental degradation. Also, considerable research has been carried out to reduce bycatch in many of the world's fisheries. Most of this work has been concentrated on trawled gears (e.g. Trawl, dredges, etc.) and less attention has been directed towards reducing bycatch in immobile gears such as gillnets [15]. Of the most existing gillnet studies, most have been concentrated on knowing the effects of biotic (behavior, morphology, and vertical distribution of fish) [15] and abiotic factors (eg. hanging ratio, thickness of monofilament, and mesh size) $[10,16]$ on the selectivity in order to increase catches of the targeted species. In contrast, few studies have investigated simple changes to the technical aspects (other than mesh size) as a tool for reducing bycatch [17].

Specifically, the effect of net colour on the selectivity and catchability of gillnets has been addressed by [14]. Fishermen on the lake Volta at Kpong and other parts of the world use different colours of gillnets not knowing which colour would increase their catch since particular notice has not been taken. It is in this vain that this work was carried out in order to know which net colour attracts more fish or is more invisible to the fish or a particular species of fish in order to reduce cost and degradation as a result of efforts to increase catch. This study is therefore aimed at identifying the type and number of fish species captured by each net colour as well as determine the morphometric characteristics of fish species caught by each net [18].

\section{Materials and Methods}

\section{Study Area}

The study was carried out in Kpong located in the Lower Manya Krobo District of the Eastern Region of Ghana. It is particularly noted for the Kpong Dam. It's located at 6 9' N, $040^{\prime} \mathrm{E}$ and an elevation of $20 \mathrm{~m}$ above sea level and at the strata II of the Volta Lake (Figure 1).

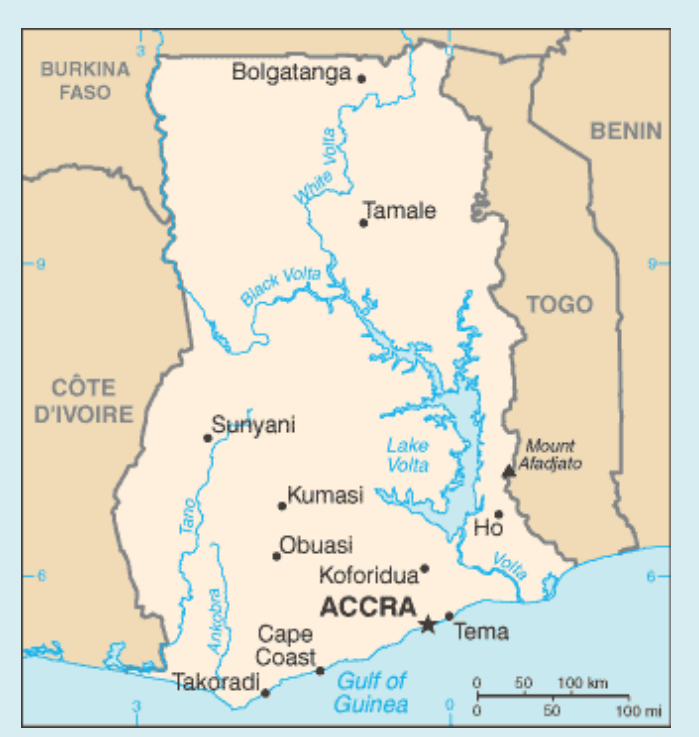

Figure 1: Map of Ghana showing the study area. 


\section{Data Collection}

Capture experiment was carried out simultaneously in the Lake Volta at Kpong from January to March using monofilament gillnets. A total of 3 monofilament gillnets were used, these had different colours thus white, brown, and green. All other characteristics of the nets such as length, height, and mesh size were similar. The mesh size of the nets was $36 \mathrm{~mm}$ whiles its length was $92.2 \mathrm{~m}$ with forty-nine (49) lead and 17 floats each. Bottles filled with sand were tied to the lower part of the net serving as extra weight to ensure that the net sinks into the water well. The top line was then tied to a tree on the river bank to secure the net after which the net was dropped and spread across the water body. The top line was then re-tied to drop the net farther in the water. During retrieval, 1 part of the top line was removed and the net pulled to the other side after which the other part of the top line tied to the tree was removed.

The nets were set once in a week and for 13 hours thus $6 \mathrm{pm}$ to $7 \mathrm{am}$, species caught by each net were assessed and identified using the taxonomic identification keys by [18] after which fishes from each net were counted, length taken using a meter board and weighed using a weighing scale for each species.

\section{Data Analysis}

The data obtained was analyzed using Microsoft Excel and presented using descriptive statistics such as tables and bar charts for easy comparison. ANOVA and t-test were executed to test the significance of differences in the number, weight, and length of fish caught in the different-colored gillnets.

\section{Results}

\section{Fish Species Caught by the Various Nets}

A total of 18 species, 78 fishes were caught during the three months experiment as shown in table 1. Species caught consists of Clarias gariepinus, Marcusenius abadii, Synodontis ocellifer, Synodontis schall, Sarotherodon galilaeus, Hemichromis fasciatus, Mormyrops anguilloides, Marcusenius senegalensis, Chrysichthys auratus, Gymnarchus niloticus, Parachanna obscura, Tilapia zillii, Mormyrops breviceps, Heterotis niloticus, Synodontis bastiani, Chromidotilapia guntheri, Oreochromis niloticus, and Polypterus senegalus (Figure 2).

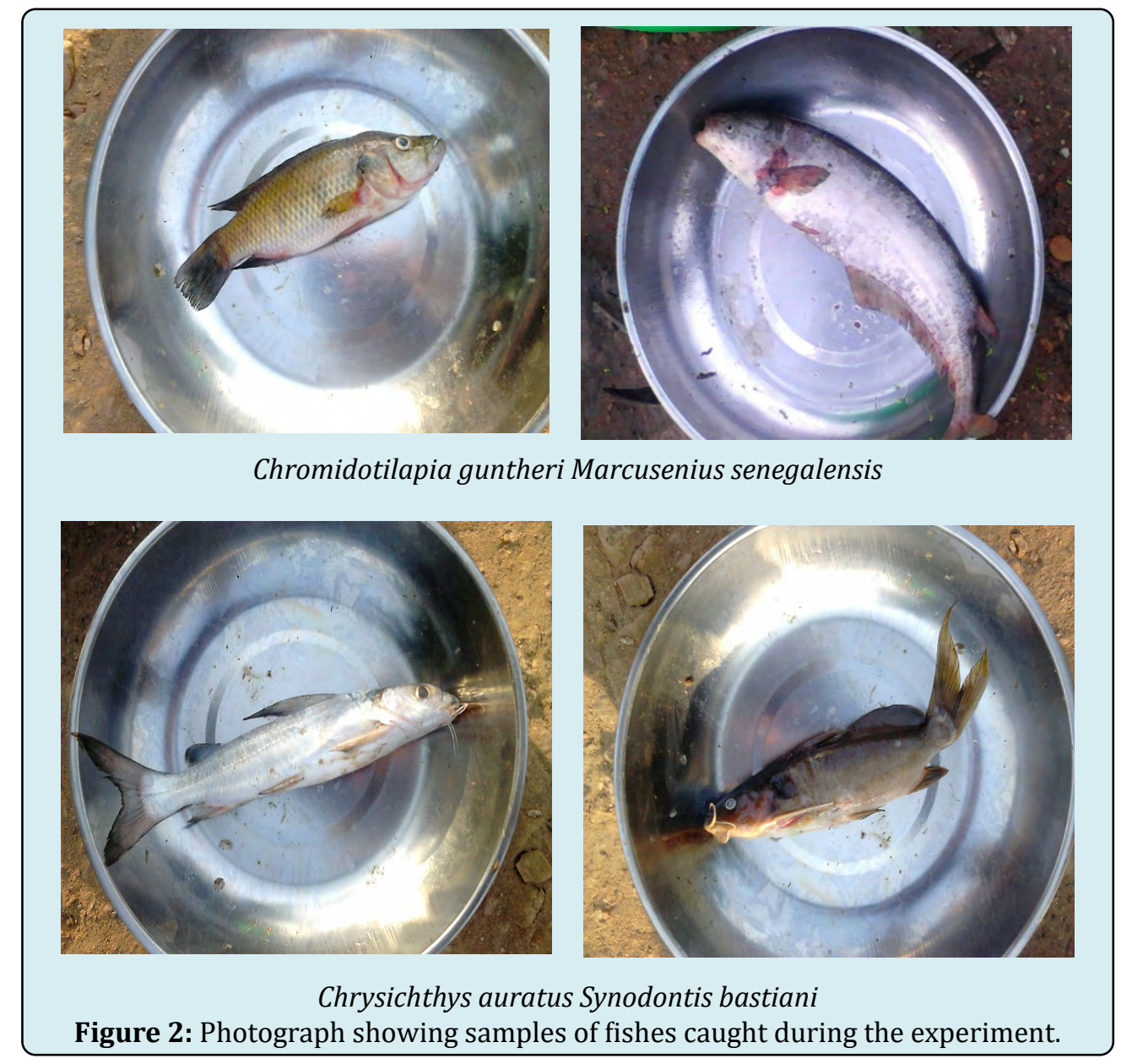

Hlordzi V, et al. Effect of Net Colours on Efficiency of Monofilament Gillnets for Catching Some Fish Species in the Lake Volta at Kpong. Int J Oceanogr Aquac 2020, 4(1): 000181. 
Green net caught the most number of fishes constituting $46.8 \%$ of the total fish caught with a weight of $42.2 \%$, followed by a white net which had $35 \%$ of the total catch and weight of $42.1 \%$ and brown net caught $18.2 \%$ of the total catch with a weight of $15.7 \%$ during the experiment.

The green net caught the highest number of species and fishes as shown in table 2 thus 14 species and 36 fishes out of the 78 fishes caught by all the 3 nets with $M$. abadii and $S$. ocellifer been the highest number of species caught, having 6 individual species each constituting $16.7 \%$ each of the total catch by the green net (Table 1). Other species caught by the green net include $S$. galilaeus, $H$. fasciatus, $M$. anguilloides, $M$. senegalensis, $C$. auratus, $G$. niloticus, P. obscura, $O$. niloticus, $P$. senegalus, C. guntheri, S. schall, and H. niloticus.

\begin{tabular}{|c|c|c|c|c|c|c|c|}
\hline Species & $\begin{array}{c}\text { Green } \\
\text { net }\end{array}$ & $\begin{array}{c}\text { White } \\
\text { net }\end{array}$ & $\begin{array}{c}\text { Brown } \\
\text { net }\end{array}$ & $\begin{array}{c}\text { Number of } \\
\text { species caught }\end{array}$ & $\begin{array}{c}\text { Weight of species } \\
\text { caught (g) }\end{array}$ & $\begin{array}{c}\text { \% number of } \\
\text { species caught }\end{array}$ & $\begin{array}{c}\text { \%weight of } \\
\text { species caught }\end{array}$ \\
\hline C. gariepinus & - & + & - & 4 & 1129.6 & 5.18 & 13.35 \\
\hline M. abadii & + & + & + & 16 & 1629.07 & 20.51 & 19.26 \\
\hline S. ocellifer & + & + & + & 14 & 846.47 & 17.95 & 10.01 \\
\hline S. galilaeus & + & + & + & 7 & 446.6 & 8.97 & 5.26 \\
\hline H. fasciatus & + & + & + & 7 & 528.6 & 8.97 & 6.24 \\
\hline M. anguilloides & + & - & + & 3 & 602.2 & 3.84 & 7.11 \\
\hline M. senegalensis & + & - & + & 2 & 275.7 & 2.56 & 3.25 \\
\hline C. auratus & + & + & - & 6 & 683 & 7.69 & 8.07 \\
\hline G. niloticus & + & - & + & 2 & 393.5 & 2.56 & 4.64 \\
\hline P. obscura & + & - & - & 1 & 279.5 & 1.28 & 3.5 \\
\hline T. zillii & - & + & - & 3 & 192 & 3.84 & 2.26 \\
\hline O. niloticus & + & + & - & 5 & 771 & 6.41 & 9.11 \\
\hline P. senegalus & + & - & - & 1 & 60 & 1.28 & 0.7 \\
\hline S. bastiani & - & + & - & 1 & 120.2 & 1.28 & 1.41 \\
\hline C. guntheri & + & - & - & 1 & 86.2 & 1.28 & 1.01 \\
\hline S. schall & + & - & - & 1 & 45.2 & 1.28 & 0.52 \\
\hline M. breviceps & - & - & + & 1 & 50.2 & 1.28 & 0.58 \\
\hline H. niloticus & + & - & - & 3 & 315.4 & 3.84 & 3.72 \\
\hline
\end{tabular}

Table 1: Percentage distribution of fish species caught.

Note: + represent species caught by the net and - species not caught by the net.

The white net caught the next highest number of fishes with $M$. abadii having the highest number thus 6 out of the 27 fishes caught by this net, which constituted $22.2 \%$ of total fish caught by this net. A total of 9 species were caught which were C. gariepinus, M. abadii, S. ocellifer, S. galilaeus, $H$. fasciatus, C. auratus, T. zillii, $O$. niloticus, and S. bastiani.
The brown net caught the least number of fishes thus 15 and 8 species. M. abadii was the highest caught specie in this net which contributed 4 out of 15 species caught constituting $28.6 \%$ of the total catch by the net. Other species caught by the net were $S$. ocellifer, $S$. galilaeus, $H$. fasciatus, $M$. anguilloides, $M$. senegalensis, $G$. niloticus, and $M$. breviceps (Table 2).

\begin{tabular}{|c|c|c|c|c|c|c|}
\hline Species & $\begin{array}{c}\text { No. of fishes } \\
\text { caught by } \\
\text { green net }\end{array}$ & $\begin{array}{c}\text { Weight of } \\
\text { fishes caught by } \\
\text { green net(g) }\end{array}$ & $\begin{array}{c}\text { No. of fishes } \\
\text { caught by } \\
\text { white net }\end{array}$ & $\begin{array}{c}\text { Weight of fishes } \\
\text { caught by white } \\
\text { net(g) }\end{array}$ & $\begin{array}{c}\text { No. of fishes } \\
\text { caught by } \\
\text { brown net }\end{array}$ & $\begin{array}{c}\text { Weight of fishes } \\
\text { caught by brown } \\
\text { net(g) }\end{array}$ \\
\hline C. gariepinus & & & 4 & 1129.6 & & \\
\hline M. abadii & 6 & 685.6 & 6 & 609.7 & 4 & 333.77 \\
\hline S. ocellifer & 6 & 334.2 & 5 & 378.4 & 3 & 133.87 \\
\hline
\end{tabular}




\begin{tabular}{|c|c|c|c|c|c|c|}
\hline S. galilaeus & 2 & 103.1 & 2 & 140.2 & 3 & 203.3 \\
\hline H. fasciatus & 5 & 390.5 & 1 & 42.7 & 1 & 95.4 \\
\hline M. anguilloides & 2 & 293.8 & & & 1 & 380.7 \\
\hline M. senegalensis & 1 & 154.8 & & & 1 & 120.9 \\
\hline C. auratus & 3 & 418.2 & 3 & 264.8 & & 99 \\
\hline G. niloticus & 1 & 195 & & & 1 & 198.5 \\
\hline P. obscura & 1 & 279.5 & & & & \\
\hline T. zillii & & & 3 & 192 & & \\
\hline M. breviceps & & & & & 1 & 50.2 \\
\hline H. niloticus & 3 & 315.4 & & & & \\
\hline S. bastiani & & & 1 & 120.2 & & \\
\hline C. guntheri & 1 & 86.2 & & & & \\
\hline O. niloticus & 3 & 176 & 2 & 595 & & \\
\hline P. senegalus & 1 & 60 & & & & \\
\hline S. schall & 1 & 45.6 & & & & \\
\hline
\end{tabular}

Table 2: Number and weight of species caught by each net colour.

\section{Statistical Analysis of Weight, Number of Fishes and Number of Fish Species Caught}

T-test analysis revealed there was significant difference in the number of fishes, number of species, and weight of fishes caught by all the 3 different net colours. The significant difference was between the number of species caught by the green and brown net, white and green and white and brown net, weight of fishes caught by the white and brown net whiles there was a significant difference between all the three nets for the total number of fishes caught by each net as shown in Figure 3.

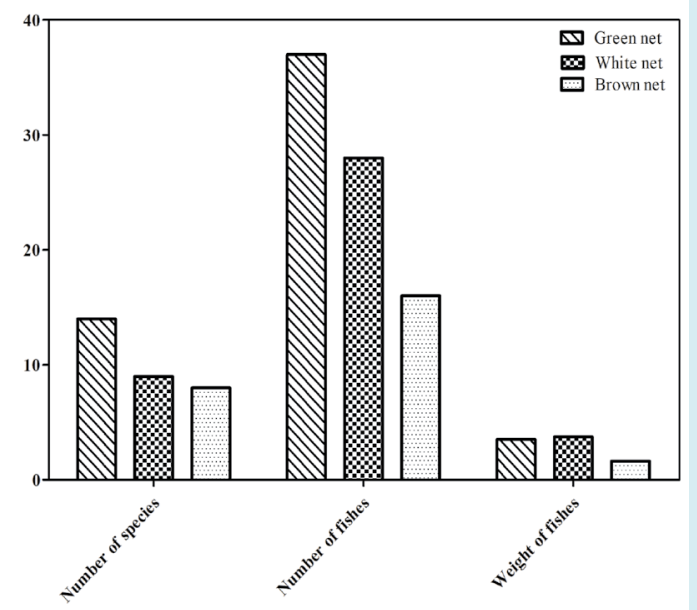

Figure 3: Graph showing difference in weight length and number of species caught by each net.

\section{Discussion}

Fish have different reactions against different net colours which may affect the efficiency of the nets $[13,16]$ however, this has not been fully investigated. In this study, green net caught the highest number of species and fishes which may be due to masking of the colour of the net with that of the water as a result of the growth of green algae in the water (less visibility to the fish) where this experiment was conducted. Similar to our finding, [19] concluded from their study that green net caught the most species hence has the best economic efficiency [20] also documented green net to be effective in capturing cod in the west part of Baltic Sea. However, lower catching efficiency was recorded by both dark and light green nets when compared to red, yellow, brown, and blue gillnets in Turkey (lake Beyșehir) [21]. The white net caught the next highest number of fish species followed by the brown net. This contradicts the findings of [22] where the white net caught the highest fish species in inland waters of Burla, India. The least catch recorded by the brown net may be due to its inability to blend well with the water, thus it was avoided by most fish species.

P. obscura, C. guntheri and S. schall were caught by only the green net which might be because the fish detected the other net colours except for the green hence they unknowingly tried swimming through the mesh of the green net where they were trapped. Species such as M. anguilloides, $M$. senegalensis, and $G$. niloticus were caught by only the green and brown nets. M. breviceps was caught by brown net only which could be attributed to the attraction of the fish to the colour brown. As stated by the reaction of fish to net colours 
varies with different fish species, which could be the reason for the different coloured nets capturing different fish species [16].

\section{Conclusion}

In conclusion, the green net had the highest catching efficiency followed by white and brown nets. From Table $1, M$. abadii was the most specie captured in this experiment while P. obscura, P. senegalus, S. bastiani, S. schall, M. breviceps, and C. guntheri were the least. P. obscura, C. guntheri, and S. schall were captured by green net only, C. gariepinus, T. zillii, and $S$. bastiani was captured by white net only and $M$. breviceps was captured by brown net only.

From this study, we recommend that more research should be conducted on colour efficiency of gillnets to enhance the efficiency of fishermen. Also, other aspects such as the effects of hanging ratio and thickness on the efficiency of the monofilament gillnets should be investigated. We also recommend that the study period of this experiment be extended in order to establish a year-long efficiency of the different net colours.

\section{References}

1. Food and Agriculture Organization of the United Nations (2016) The State of World Fisheries and Aquaculture 2016. Contributing to food security and nutrition for all, Rome, pp: 200.

2. Gabriel O, Lange K, Dahm E, Wendt T (2008) Von Brandt's fish catching methods of the world, $4^{\text {th }}$ (Edn.), John Wiley \& Sons.

3. Mead D (2013) Fishing gear. Sulawesi language alliance.

4. Ambrose E, Isangedighi I (2016) The Operational Perspective of Monofilament and Multifilament Gillnets in Catching Chrysichthys Nigrodigitatus in Cross River Estuary. Coropus.

5. Gray CA, Broadhurst MK, Johnson DD, Young DJ (2005) Influences of hanging ratio, fishing height, twine diameter and material of bottom-set gillnets on catches of dusky flathead Platycephalus fuscus and non-target species in New South Wales, Australia. Fish Sci 71: 12171228.

6. Sainsbury JC (1996) Commercial fishing methods: an introduction to vessels and gears.

7. Atar HH, Ölmez M, Bekcan S, Seçer S (2002) Comparison of three different traps for catching blue crab (Callinectes sapidus Rathbun 1896) in Beymelek Lagoon, Turkish J
Vet Anim Sci 26: 1145-1150.

8. Hovgård H (1996) A two-step approach to estimating selectivity and fishing power of research gill nets used in Greenland waters, Can J Fish Aquat Sci 53(5): 10071013.

9. Hovgård H (1996) Effect of twine diameter on fishing power of experimental gill nets used in Greenland waters. Cand J Fish Aquat Sci 53(5): 1014-1017.

10. Hovgêrd H, Lassen $H$ (2008) Manual on estimation of selectivity for gillnet and longline gears in abundance surveys. Food \& Agriculture Org.

11. Karlsen L, Bjarnason BA (1987) Small-scale fishing with driftnets. Food \& Agriculture Org.

12. Njoku DC (1991) Comparative efficiency and technoeconomics of multifilament and monofilament gillnets on the Oguta Lake, Nigeria. Fish Res 12(1): 23-30.

13. Backiel T, Welcomme RL (1980) Guidelines for sampling fish in inland waters. Food and Agriculture Organization of the United Nations, Rome, Italy, pp: 1-33.

14. Wardle CS, Cui G, Mojsiewicz WR, Glass CW (1991) The effect of colour on the appearance of monofilament nylon under water. Fish Res 10(3-4): 243-253.

15. McCombie AM, Berst AH (1969) Some effects of shape and structure of fish on selectivity of gillnets. J Fish Board Canada 26(10): 2681-2689.

16. Hamley JM (1975) Review of gillnet selectivity. J Fish Board Canada 32(11): 1943-1969.

17. Godøy H, Furevik DM, Stiansen S (2003) Unaccounted mortality of red king crab (Paralithodes camtschaticus) in deliberately lost pots off Northern Norway. Fish Res 64(2-3): 171-177.

18. Dankwa HR, Abban EK, Teugels GG (1999) Freshwater fishes of Ghana: identification, distribution, ecological and economic importance.

19. Radfar F, Ansari H, Gerami MH, Dastbaz M (2015) Economic performance efficiency of gillnet based on mesh size and net color. Int J Mar Sci 5(7): 1-4.

20. Steinberg R (1985) Fisheries with gill and trammel nets and their applicability in the Baltic and North Sea. Fishereitech 15(68): 7-96.

21. Balik I, Cubuk H (2001) Effect of net colours on efficiency of monofilament gillnets for catching some fish species in Lake Beyşehir. Turkish J Fish Aquat Sci 1: 29-32.

22. Narayanappa G, Khan AA, Naidu MR (1977) Coloured gill nets for reservoir fishing. Fish Technol 14(1): 44-48.

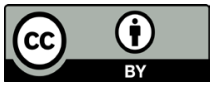

Hlordzi V, et al. Effect of Net Colours on Efficiency of Monofilament Gillnets for Catching Some Fish Species in the Lake Volta at Kpong. Int J Oceanogr Aquac 2020, 4(1): 000181. 